\title{
DAMPAK KAPITALISME PERKEBUNAN TERHADAP PERUBAHAN KEBUDAYAAN MASYARAKAT DI KAWASAN SUBANG 1920 - 1930*
}

\author{
THE IMPACT OF PLANTAGE CAPITALISM TO THE CULTURAL CHANGE \\ IN SUBANG AREA \\ $1920-1930$
}

Iim Imadudin

Balai Pelestarian Nilai Budaya Bandung

Jln. Cinambo No.136 Ujungberung-Bandung 42094

e-mail: iim.imadudin@yahoo.com

Naskah Diterima:8 Januari 2014 Naskah Direvisi:12 Februari $2014 \quad$ Naskah Disetujui:18 Februari 2014

\begin{abstract}
Abstrak
Sektor perkebunan memiliki peran yang besar dalam dinamika masyarakat Indonesia sejak masa kolonial hingga sekarang. Dengan kata lain, sejarah Indonesia tidak dapat dipisahkan dari sektor perkebunan. Keterkaitan itu yang mencuatkan pandangan bahwa sejarah kolonialisme Barat di Nusantara tidak lain adalah sejarah perkebunan. Hal tersebut tergambarkan dalam kenyataan, bahwa selama lebih dari satu abad, perkebunan menjadi aspek terpenting pada masa penjajahan. Berbagai realitas ekonomi dan sosial masyarakat di berbagai wilayah di Indonesia tumbuh sebagai konsekuensi logis kehadiran perkebunan. Berkembangnya industri perkebunan mengubah segisegi kehidupan masyarakat secara mendasar dengan masuknya faktor produksi, seperti tanah, tenaga kerja, dan modal. Di kawasan Subang, sejak awal abad ke-19, berdiri tanah partikelir Pamanukan dan Ciasem yang kemudian mengembangkan berbagai perkebunan besar yang berorientasi ekspor. Sejumlah perkebunan mengalami perkembangan yang pesat di bawah kepemimpinan Hofland di pertengahan abad ke-19 sampai paruh pertama abad ke-20. Penelitian yang mempergunakan metode sejarah ini bertujuan menjelaskan keberadaan industri perkebunan dalam konteks perubahan kebudayaan masyarakat. Hasil penelitian menunjukkan bahwa masyarakat setempat yang hidup dalam tradisi agraris tradisional harus beradaptasi dengan ekonomi perkebunan. Selain itu, para pendatang yang berasal dari berbagai daerah juga memberi corak yang khas dalam perubahan budaya masyarakat. Budaya masyarakat yang terikat dengan ekonomi subsistensi berubah menjadi ekonomi uang sehingga terjadi perubahan kebudayaan.
\end{abstract}

Kata kunci: kapitalisme perkebunan, perubahan kebudayaan, Subang.

Abstract

Plantage sector has a great influence on the dynamics of Indonesian society since the colonial era until now. With other words, the history of Indonesia cannot be divided with plantage sector. Colonialism in Nusantara was affected by the history of the plantage history itself. For more than one century, plantage became the most important thing in colonialism era. Economic and social reality in Indonesia grows up as logical consequences of plantage appearance. The

*Sebagian data artikel ini berasal dari tesis penulis pada Program Pendidikan Magister Fakultas Ilmu Budaya Konsentrasi Ilmu Sejarah Universitas Padjadjaran dengan judul "Kehidupan Sosial Ekonomi Buruh di Tanah Partikelir Pamanukan dan Ciasem 1910-1969” (2013). 
dynamics of plantage sector has changed the society, especially with the entry of productions factor, such as land, labor, and capital. In Subang area, since the beginning of the 19th century, pop out the private land of Pamanukan and Ciasem which branching out big company of plantation and focused on export. Number of plantage faced rapidly grow in the middle of 19th until beginning of 20th century under the hand of Hofland as the leader. The purpose of the research is to describe the existences of plantage industry in the context of culture changed in society. The result of the research show us that the society who lived in traditional agrarian must adapt with the plantage economics. Besides that, comers from many areas also influenced the changing of cultural society. The culture of the society which bound up with the economy has changed become capitalist economy, in such a way changed the culture itself.

Keywords: capitalism, plantage, cultural change, Subang.

\section{A. PENDAHULUAN}

Sistem kebun prakapitalisme pada mulanya merupakan sistem usaha pertanian tradisional yang telah ada sebelum masuknya VOC. Ciri-ciri perkebunan tradisional adalah bentuk usahanya kecil, penggunaan lahan terbatas, tidak padat modal, sumber tenaga kerja berpusat pada anggota keluarga, lebih berorientasi pada kebutuhan subsistensi (Mubyarto et al., 1992: 16). Pada perkembangannya sistem usaha kebun menjadi perekonomian pertanian komersial yang bercorak kolonial. Sistem perkebunan ini dibawa oleh perusahaan kapitalis asing yang sebenarnya merupakan Sistem Perkebunan Eropa (European Plantation). Perkebunan merupakan bagian dari sistem perekonomian pertanian komersial yang diwujudkan dalam bentuk usaha pertanian komersial dalam skala besar dan kompleks. Adapun sifat dari pertanian komersial adalah padat modal (capital intensive) dengan penggunaan lahan yang luas, organisasi tenaga kerja yang besar dengan pembagian kerja yang rinci, berteknologi modern, spesialisasi, serta sistem administrasi dan birokrasi (Pahan, 2008: 42).

Proses transformasi sistem usaha kebun (tradisional) ke perusahaan perkebunan (komersial) di Hindia Belanda ketika itu dilatarbelakangi perubahan kebijakan politik kolonial. Pertumbuhan sistem perkebunan pada masa kolonial terdiri dari dua fase perkembangan, yaitu industri perkebunan negara yang kemudian beralih ke industri perkebunan swasta. Sistem Tanam Paksa (Cultuur Stelsel) merupakan bentuk perwujudan industri perkebunan negara yang merupakan kelanjutan dari politik eksploitasi VOC (Verenigdee Oost Indische Compagnie).

Apabila pada zaman VOC eksploitasi dilakukan secara tidak langsung oleh kepala pemerintahan feodal, tindakan eksploitasi baru tersebut dilakukan secara langsung menggunakan sistem perkebunan negara. Pelaksanaan sistem tersebut dilaksanakan melalui alat birokrasi pemerintah yang berfungsi langsung sebagai pelaksana dalam proses mobilisasi sumber daya perekonomian agraris tanah jajahan, yaitu penguasaan terhadap tanah dan tenaga kerja (O'Malley, 1988: 228; Pahan, 2008: 43).

Selanjutnya, pada tahun 1870-an berlangsung perubahan kebijakan politik kolonial setelah beralihnya kebijakan politik konservatif menjadi kebijakan politik liberal, yaitu dengan dikeluarkannya Agrarische Wet (Undang-undang Agraria). Implikasinya, politik eksploitasi yang semula dikelola oleh perusahaan negara diganti dengan perusahaan swasta. Perubahan tersebut ditandai oleh meningkatnya gelombang pembukaan industri perkebunan yang dilakukan oleh para pengusaha Eropa di tanah jajahan (Pahan, 2008: 43).

Setelah tahun 1870, komersialisasi meluas di Hindia Belanda. Hak erfpacht yang dijamin dalam UU Agraria 1870 memungkinkan penguasaan lahan dengan luas maksimal 350 ha (1.500 bau) selama 75 tahun. Para planter (pengusaha perkebunan) perseorangan yang telah berpengalaman dengan teknik produksi tanaman pada masa Cultuur Stelsel segera 
memanfatkan peluang bisnis tersebut (Pahan, 2008: 43; O’Malley, 1988: 230).

Secara filosofis, meski para penganjur liberalisme di Negeri Belanda mengecam peranan negara dalam sistem tanam paksa, mereka tetap memandang Hindia Belanda sebagai suatu "perusahaan" yang harus menghasilkan laba. Apabila Van den Bosch memandang Hindia Belanda sebagai suatu perusahaan negara, kaum liberal menganggap koloni mereka sebagai suatu perusahaan swasta (Poesponegoro dan Nugroho Notosusanto, 2008: 122).

Bagaikan dua sisi dari mata uang, perkembangan perkebunan modern dapat digambarkan demikian. Di satu sisi keberadaan onderneming menjadi jembatan yang menghubungkan masyarakat Indonesia dengan ekonomi dunia. Keterlibatan dalam sistem ekonomi dunia melalui perkebunan besar memberikan surplus finansial yang tinggi dan membuka kesempatan ekonomi baru. Akan tetapi di sisi lain, terdapat dampak yang merugikan. Diversifikasi ekonomi masyarakat secara lebih luas menjadi terhambat, sumber penindasan, serta berperan cukup besar dalam menyuburkan kemiskinan struktural di kalangan masyarakat (Purwanto, 2007: 1).

Di wilayah Subang, masuknya kapitalisme perkebunan pada abad ke-19 dan 20 dimulai dengan penjualan tanah partikelir Pamanukan dan Ciasem (selanjutnya disingkat $\mathrm{P}$ en $\mathrm{T}$ ) ke tangan swasta. Perkebunan Pamanoekan dan Tjiasem didirikan pada tahun 1812. Berdirinya perusahan P\&T Lands dilatarbelakangi oleh krisis keuangan pada masa Thomas Stamford Raffles (Asdi et al., 2007: 30).

Penetrasi kapitalisme perkebunan ke wilayah Subang menarik untuk dikaji dalam perspektif transformasi kebudayaan. Intervensi perkebunan besar dari sisi ekonomi telah menciptakan keuntungan yang besar para pemilik perkebunan. Kemajuan ekonomi juga tampak mengembangkan masyarakat di wilayah perke- bunan. Namun dari sisi yang lain, modernisasi perkebunan secara nyata mengubah masyarakat agraris dari petani menjadi buruh. Buruh yang tadinya merupakan petani bertranformasi menjadi buruh, karena tidak lagi memiliki tanah. Padahal secara kultur, menjadi buruh bukanlah pilihan yang diinginkan. Namun adaptasi terhadap perubahan harus dilakukan. Artikel ini meninjau model perubahan kebudayaan dalam perubahan mata pencaharian dan gaya hidup.

\section{B. METODE PENELITIAN}

Penelitian ini menggunakan metode sejarah, yang terdiri atas empat tahapan. Tahap pertama adalah heuristik, yaitu proses mencari, menemukan, dan menghimpun sumber sejarah yang bersesuaian dengan pokok masalah. Pencarian sumber dilakukan terhadap sumber tertulis berupa arsip, sumber resmi tercetak, dokumen, buku, dan sebagainya. Setelah proses heuristik, kemudian dilakukan kritik yang terdiri atas kritik ekstern dan kritik intern. Kritik ekstern bertujuan untuk menentukan otentisitas, sedangkan kritik intern dilakukan dengan melakukan penilaian mengenai kredibilitas sumber tersebut. Selain itu, dilakukan pula proses koroborasi untuk mendapatkan sumber yang kredibel. Selanjutnya, tahap ketiga adalah interpretasi, yaitu proses menafsirkan fakta-fakta menjadi sebuah rangkaian yang logis. Interpretasi dilakukan secara analitis (menguraikan fakta) dan sintesis (menghimpun fakta). Tahap terakhir dari metode sejarah adalah historiografi. Pada tahap ini, interpretasi terhadap fakta ditulis secara sistematis dan kronologis.

Secara metodologis, penelitian ini menggunakan pendekatan ilmu sosial. Konsep-konsep dalam ilmu sosial digunakan untuk memperkuat eksplanasi dan interpretasi (Suhartono, 2010: 131). Secara lebih spesifik, digunakan pendekatan sosiologi yang meneropong segi-segi tertentu dari suatu peristiwa. Dalam hal ini, golongan sosial yang berperan, nilainilainya, hubungan dengan golongan lain, 
konflik yang didasarkan pada kepentingan ideologi, dan seterusnya (Kartodirdjo, 1992: 4).

Pendekatan antropologi digunakan berkenaan dengan penggunan konsep dan teori perubahan kebudayaan. Asumsi dasar dari penelitian ini adalah bahwa kebudayaan berkembang sejalan dengan perkembangan pemikiran manusia. Kebudayaan bukanlah sesuatu yang given (telah jadi), melainkan berkembang menurut zamannya. Dengan kata lain, transformasi kebudayaan berada dalam ruang dan waktu (Endraswara, 2006: 22). Perubahan sosial dan kebudayaan biasanya disebabkan oleh adanya perubahan luar biasa dalam sistem politik, ekonomi, dan teknologi (Suparlan, 1995: 64). Secara teoretis, perubahan kebudayaan mencakup lima hal pokok. Pertama, perubahan sistem nilai yang prosesnya mulai dari penerimaan nilai baru dengan proses integrasi ke disintegrasi untuk selanjutnya menuju reintegrasi. Kedua, perubahan sistem makna dan sistem pengetahuan yang berupa penerimaan suatu kerangka makna (kerangka pengetahuan), penolakan, dan sikap penerimaan makna baru dengan proses orientasi ke disorientasi ke reorientasi sistem kognitifnya. Ketiga, perubahan sistem tingkah laku yang berproses dari penerimaan tingkah laku baru. Keempat, perubahan sistem interaksi, di mana akan muncul gerak sosialisasi melalui disosialisasi ke resosialisasi. Kelima, perubahan sistem kelembagaan/ pemantapan interaksi, yaitu pergeseran dari tahapan organisasi ke disorganisasi ke reorganisasi (Syam, 1997: 160).

Faktor penyebab perubahan kebudayaan ada yang berasal dari dalam (sebab intern), dan juga dari luar (sebab ekstern). Sebab dari dalam masyarakat, yaitu munculnya berbagai bentuk pertentangan (konflik) dalam masyarakat sehingga adanya kesenjangan sosial antarsesama warga, adanya dinamika penduduk, pertambahan dan penurunan jumlah penduduk, adanya penemuan-penemuan baru dalam masyarakat (discovery), dan penemuan yang menyempurnakan bentuk penemuan lama (invention), dan pemberontakan atau revolusi. Adapun sebab-sebab dari luar masyarakat, yaitu terjadinya peperangan, adanya pengaruh bencana alam, dan adanya pengaruh kebudayaan masyarakat lain (Soekanto, 2006: 282).

Dalam kaitannya dengan relasi antara kapitalisme atau modernisasi dengan perubahan kebudayaan, ada dua kutub yang bertentangan secara tajam. Teori modernisasi yang diintroduksi Karl Marx menyatakan bahwa pembangunan ekonomi akan memudarkan nilai-nilai lama. Sementara itu, Huntington dan Weber berpendapat bahwa nilai budaya pada dasarnya merupakan pengaruh yang bersifat otonom dalam masyarakat (Inglehart and Wayne E Baker, 2000).

\section{HASIL DAN BAHASAN}

\section{Gambaran Umum Kawasan Subang}

Dalam artikel ini, yang dimaksud Subang bukanlah "kota Subang", melainkan "kawasan Subang". Kawasan Subang mencakup kota Subang dan daerah-daerah di sekitarnya. Dengan demikian, luas kawasan Subang dapat diperbandingkan dengan Kabupaten Subang sekarang. Hal tersebut tidak terhindarkan, karena berkaitan dengan latar historis berkembangnya perusahaan perkebunan di wilayah Subang.

Pembentukan Kota Subang terkait erat dengan tumbuhnya perkebunanperkebunan besar yang berada di tanah partikelir P en T Lands. Pada waktu itu, Kota Subang menjadi pusat administrasi $\mathrm{P}$ en $T$ Lands sejak dibangunnya kantor induk administrasi. Selanjutnya, untuk memenuhi keperluan sosial-ekonomi pegawai perkebunan dibangun pula perumahan pegawai, rumah sakit, gudang, pabrik, bengkel, dan sekolah. Oleh karena itu, dapat dikatakan bahwa perkebunan memberi corak kekotaan yang khas pada wilayah ini. Pengaruhnya, terutama pada pembentukan corak kehidupan sosial, ekonomi, dan budaya masyarakat di wilayah Subang. Kondisi tersebut selaras 
dengan perkembangan kota-kota pedalaman yang didorong oleh industri perkebunan pada paruh kedua abad ke-19 (Padmo, 2007: 1).

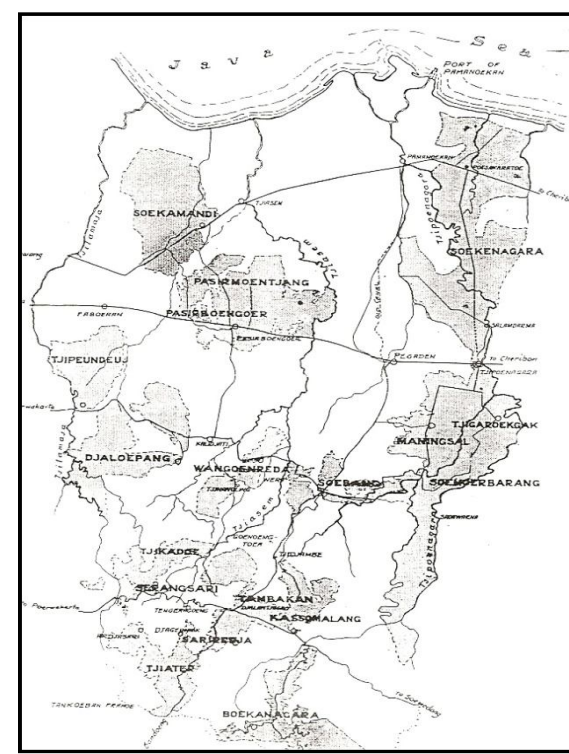

Gambar 1. Kawasan perkebunan di wilayah Subang.

Sumber: diakses dari:

http://blog.seniorennet.be, 6 Januari 2014 Pukul 11.03 WIB.

Wilayah Subang berbatasan dengan Laut Jawa di sebelah utara; Sungai Cilamaya di sebelah barat; sebagian Sungai Cipunagara dan sebagian lagi batas Keresidenan Cirebon di sebelah timur; dan tanah-tanah terbentang sampai Gunung Tangkubanperahu di sebelah selatan (Effendhie, 1990: 1).

Dari segi topografis, wilayah Subang bervariasi, mulai dari arah laut di utara sampai ke rangkaian pegunungan di wilayah selatan. Posisi tertinggi mencapai ketinggian 7000 kaki. Wilayah Subang dibagi ke dalam tiga zona, yaitu (1) daerah pegunungan di Subang bagian selatan, (2) daerah berbukit dan dataran rendah di Subang bagian tengah, dan (3) daerah dataran rendah dekat pantai di Subang bagian utara.

Wilayah pegunungan dengan ketinggian antara 500-1500 m dpl dengan luas 41.035,09 hektar (20\% dari seluruh luas Kabupaten Subang), meliputi Kecamatan Ciater, Kasomalang, Sagalaherang, Serangpanjang, sebagian besar Jalan Cagak dan Tanjungsiang. Selanjutnya, wilayah berbukit dan dataran dengan ketinggian antara 50-500 m dpl dengan luas wilayah 71.502,16 hektar (34,85\% dari seluruh luas Kabupaten Subang), meliputi Kecamatan Cijambe, Subang, Cibogo, Kalijati, Dawuan, Cipeundeuy, sebagian besar Kecamatan Purwadadi, Cikaum dan Pagaden Barat. Daerah dataran rendah yang berada tidak jauh dari pantai dengan ketinggian antara 0-50 m dpl seluas 92.639,7 hektar. Luas wilayah dataran rendah sekitar 45,15\% dari seluruh luas Kabupaten Subang. Daerahdaerahnya meliputi Kecamatan Pagaden, Cipunagara, Compreng, Ciasem, Pusakanagara, Pusakajaya Pamanukan, Sukasari, Legonkulon, Blanakan, Patokbeusi, Tambakan, dan sebagian Pagaden Barat. Bentang wilayah bagian barat ke timur Subang sejauh 40 kilometer, dan dari wilayah utara ke selatan 60 kilometer.

Perbedaan bentangan alam mempengaruhi karakteristik tanah yang menyebabkan komoditas yang dihasilkan berbeda-beda antara satu daerah dengan daerah lain. Tanaman teh tumbuh subur di perkebunan Bukanegara, Sarireja, Ciater, Sarangsari, dan Cipeo. Tanaman kopi di perkebunan Bukanegara, Kasomalang, Sarirejo, Sarangsari, Cipeo, Wangunreja, Pasirbungur, dan Pasirmuncang. Tanaman kina di perkebunan Bukanegara dan Ciater. Tanaman karet tumbuh dengan subur di perkebunan Sarireja, Sarangsari, Cipeo, Wangunreja, Pasirbungur, dan Pasirmuncang (Effendhie, 1990: 3).

Dahulu, orang-orang yang akan berkunjung ke kawasan Subang dapat memilih jalan darat atau laut. Jalan darat menyusuri jalur pantai utara Jawa dan dari wilayah Purwakarta atau Bandung bagian utara. Akses dari laut melalui dermaga Pamanukan yang pernah ramai pada permulaan tahun 1900-an. Saat itu permintaan luar negeri akan komoditas 
perkebunan Nusantara cukup tinggi. Lori mengangkut hasil perkebunan ke dermaga Pamanukan. Dari dermaga tersebut, komoditas perkebunan dibawa ke pulau-pulau lain di pulau Jawa, bahkan diekspor ke Eropa menggunakan kapal angkut milik perusahaan. Interaksi antarwilayah di Jawa bagian barat semakin intensif saat pembukaan jalur kereta api Cikampek-Cirebon pada 1912 (Ledeboer, tt: 6).

Sungai-sungai yang mengalir di wilayah Subang bermuara ke Laut Jawa. Sungai-sungai itu adalah Sungai Cilamaya, Sungai Blanakan, Sungai Ciasem, Sungai Cigadung, dan Sungai Cipunegara. Sungai Cilamaya yang terletak di bagian barat menjadi batas alam Kabupaten Subang dengan Kabupaten Purwakarta dan Karawang. Sementara itu, Sungai Cipunagara merupakan batas alam dengan Kabupaten Indramayu dan Sumedang.

Sungai Ciasem bermuara di Teluk Ciasem di Laut Jawa, di muara sebelah timur Blanakan. Daerah ini dipenuhi lahan persawahan dan rawa-rawa yang tidak produktif. Namun, sebagiannya telah diolah menjadi tambak ikan. Sungai Ciasem dan Cipunegara diperkirakan sudah menjadi jalur transportasi sejak masa prasejarah (Imadudin, 2013: 35).

Hutan Pamanukan dan Ciasem sejak 1677 dikenal sebagai penghasil kayu jati berkualitas. Itulah sebabnya mengapa Pemerintah Hindia Belanda ketika membangun kota Batavia menggunakan kayu jati dari Subang. Pengangkutannya dilakukan melalui sungai. Guna memperoleh hasil hutan yang lebih optimal, berbagai ekspedisi ke Pamanukan dan Ciasem. Selain untuk keperluan pembangunan kota, para pengusaha menjual kayu jati pada orang-orang Cina pembuat meubel di Bandung dan Cirebon (Ledeboer, tt: 6). Hutan yang dipenuhi pepohonan jati yang berkualitas tinggi inilah yang menjadi salah satu promosi Raffles kepada para peminat swasta ketika menjual tanah Pamanukan dan Ciasem (Ledeboer, tt: 25). Dengan karakteristik topografis yang spesifik, wilayah Subang menjadi area perkebunan yang subur. Berbagai komoditas perkebunan tumbuh dengan subur di dataran tinggi maupun pesisir Subang.

\section{Perkembangan Perkebunan di Kawasan Subang}

Pada masa para perintis yang membuka lahan perkebunan, tanah-tanah $\mathrm{P}$ en $\mathrm{T}$ di kawasan Subang masih berupa lahan yang tidak produktif. Kawasan ini dapat dikatakan belum menghasilkan komoditas yang penting. Para penduduk bersawah, serta bertanam kelapa dan kopi. Umumnya kelapa tumbuh di dataran rendah bagian utara yang berpantai. Aktivitas ekonomi tradisional penduduk, antara lain pembuatan gula dan arak yang dibuat dengan cara yang sangat sederhana dari aren. Bahan pohon aren tumbuh subur di daerah Sagalaherang (ANRI, 1976: XLII).

Perkembangan perusahaan $\mathrm{P}$ en $\mathrm{T}$ mulai nampak saat Skelton menguasai tanah ini. Dikelolanya lahan P en T hingga 1821. Dalam perkembangannya, kepemilikan perusahaan $\mathrm{P}$ en $\mathrm{T}$ berpindah-pindah di antara pengusaha berkebangsaan Inggris. Pada 1830, tanah P en T dikelola dengan lebih terorganisasi dengan adanya pengurus (manager) yang mampu melakukan penghematan secara ketat atas pengeluaran keuangan perusahaan. Sejalan dengan perkembangan politik dan ekonomi, pada 1839 pemerintah Hindia Belanda mengambil alih kepemilikan $\mathrm{P}$ en T (Imadudin, 2013: 59).

Tidak lama setelah pengambilalihan oleh pemerintah, pada 1840 dua bersaudara Thomas Benjamin Hofland ${ }^{1}$ dan Peter

1 Thomas Benjamin Hofland dilahir-kan di Jacana Tapoera pada 1799. Sebelum ke P en $\mathrm{T}$ Lands, ia adalah kontraktor pemerintah dan pengusaha perkebunan gula di Pasuruan. Pada 1835, ia menjadi pemilik pabrik gula Kedawoeng dan Gratie di Pasuruan. Ia meninggal di atas kapal "Pera" di wilayah antara Alexandria dan Malta dalam perjalanannya ke Eropa pada 21 Mei 1853. Ia dikuburkan di Malta (Anonim, 1971: 2). 
William Hofland, yang berkebangsaan Belanda membeli tanah-tanah $\mathrm{P}$ en $\mathrm{T}$. karena memerlukan modal tambahan untuk mengusahakan tanah-tanah tersebut, Hofland bersaudara mengubah status perusahaan menjadi N.V. Pada 1858, Peter Wiliam Hofland membeli saham saudaranya atas tanah-tanah itu. Dengan demikian, ia berkuasa penuh atas tanah $\mathrm{P}$ en T. P.W. Hofland membentuk "pemerintahan swasta" dengan mempekerjakan orang-orang pribumi menjadi demang, asisten demang, patih, mantri, opsir umbul (juru taksir cukai), upas, dan jaksa. Orangorang yang diangkat tersebut digaji pihak perkebunan. Hofland juga mengusulkan pada pemerintah agar membentuk kademangan baru (Effendhie, 1990: 2).
Di wilayah $P$ en $T$ terdapat perbedaan status tanah, yakni tanah yang diusahakan langsung dan tidak langsung. Tanah berupa areal perkebunan diusahakan langsung dikelola oleh tuan tanah. Sementara itu, penduduk mengelola tanah yang tidak diusahakan langsung meliputi persawahan, ladang, dan hunian. Bila perkebunan dipimpin administratur, tanah yang diusahakan tidak langsung dikelola demang dan aparatnya. Administratur dan demang sama-sama bertanggung jawab terhadap tuan tanah (Effendhie, 1990: 2). Beberapa perkebunan yang dibuka pada masa Hofland sebagai berikut:

Tabel 1. Nama Kebun dan Tanaman Komoditasnya

\begin{tabular}{|c|c|c|c|c|c|c|}
\hline No. & Daerah & Nama & & & noditas & \\
\hline & & & Teh & Kopi & Karet & Kina \\
\hline 1. & Batusirap & Bukanegara & $\sqrt{ }$ & $\sqrt{ }$ & & $\sqrt{ }$ \\
\hline & & Kasomalang & & $\sqrt{ }$ & & \\
\hline & & Sarireja & $\sqrt{ }$ & $\sqrt{ }$ & $\sqrt{ }$ & \\
\hline & & $\begin{array}{l}\text { Ciater } \\
\text { Jagernaek }\end{array}$ & $\sqrt{ }$ & & & $\sqrt{ }$ \\
\hline 2. & Sagalaherang & Serangsari & $\sqrt{ }$ & $\sqrt{ }$ & $\sqrt{ }$ & \\
\hline 3. & Subang & Cipeo & $\sqrt{ }$ & $\sqrt{ }$ & $\sqrt{ }$ & \\
\hline 4. & Kalijati & Wangunreja & & $\sqrt{ }$ & $\sqrt{ }$ & \\
\hline 5. & Purwadadi & Pasirbungur & & $\sqrt{ }$ & $\sqrt{ }$ & \\
\hline & & Pasirmuncang & & $\sqrt{ }$ & $\sqrt{ }$ & \\
\hline
\end{tabular}

Sumber: Disbudpar Subang, 2002

"Tangan dingin" Hofland ${ }^{2}$ mampu mengubah tanah-tanah terlantar menjadi produktif dalam tempo 32 tahun. Ia bukan sekadar pengusaha perkebunan yang handal, tetapi juga memiliki pandangan

${ }^{2}$ Peter William Hofland dilahirkan di kota Jagernaik Poeram dekat Madras India pada 1802 (Bosma and Raben, 2008:). P.W. Hofland adalah pengusaha gula di Pasuruan, dan kemudian menjadi pemilik P en T Lands. Ia menikah dengan Helena Maria van't Wout (1811-1891) di Pasuruan (Anonim, 1971: 4). yang cermat dengan mengembangkan infrastruktur di wilayahnya melalui pembangunan jalur transportasi. Di bawah kontrol Hofland, infrastruktur jalan dan jembatan terpelihara dengan baik. Ia juga mendorong tumbuhnya pasar-pasar lokal yang memperjualbelikan barang dengan harga lebih murah dibandingkan para pedagang Cina. Ia berupaya mengurangi dominasi Cina dalam perdagangan. Selain itu, Hofland membangun Sekolah Desa (Dessa Schools), dengan pengajaran bahasa Melayu dan aritmatika (Anonim, 1938: 4). Hofland berperan menjadi 
pemilik tunggal sampai ia meninggal pada 1872. Kekayaan warisan Hofland dibagibagi di antara istri dan anak-anaknya. Dalam situasi seperti ini, perusahaan $\mathrm{P}$ en $\mathrm{T}$ mengalami kemerosotan. Faktor internal dengan adanya perselisihan di antara anggota menjadi penyebabnya. Kebangkrutan perusahaan juga dipicu kecurangan dan kemampuan staf yang tidak memadai. Krisis finansial yang dihadapi perusahaan $\mathrm{P}$ en $\mathrm{T}$ kian hebat tatkala harga kopi di pasaran dunia jatuh secara drastis pada 1880 (Anonim, 1938: 4).

N.I. Handelsbank mencoba mengambil alih perusahaan. Pada 1885, bank ini menolak kredit yang diajukan anak Hofland, hingga akhirnya terbentuk N.I. Landbouw. Kedua putra Hofland kemudian membentuk N.V. Maatschapij tot Eksploitative van de Pamanoekan en Tjiasemlanden, yang terdaftar 24 Desember 1886 di Batavia dengan kapital $f$ 7.500.000. Kedua bersaudara membagi saham kepemilikan, yaitu masing-masing anak Hofland sebesar $f$ 2.587.000,00 N.I. Landbouw $f$ 1000,00; H.P. van Henkelom $f$ 10.000,00; A. Mohr, J.P. Jeanette Walen dan C.A. Henny (masing-masing) $f$ 5000,00. Saham terbesar tentu berada di tangan N.I. Landbouw Maatschapij. Dalam perkembangannya, kedua anak Hofland kehilangan haknya atas perusahaan. N.I. Landbouw yang berkedudukan di Batavia memegang kendali atas perusahaan, dengan wakil direktur dan komisaris, yaitu George Birnie, Baron Roell, dan J. St. Bowls. Kepala manajer pertama dipegang St. Bowls, seorang pengusaha gula. Di bawah manajemennya didirikan pabrik gula di Subang. Karena mewabahnya penyakit tebu, pabrik ini ditutup. St. Bowls digantikan van Henkelom (Anonim, 1938: 4).

Sesudah 1901, tidak ada manajer kepala yang diangkat. Akan tetapi, tidak lama kemudian manajemen diambil alih Scluter, perwakilan N.I. Landbouw di Batavia. Kemudian, Scluter diteruskan Jaansen van Raay pada 1903. Ia mengembangkan tanaman kopi robusta di perusa- haan kopi Jagernaik. Ia pun berupaya mengembangkan tanaman padi, tetapi tidak berhasil. Kepemimpinan Jaansen van Raay berakhir pada 1908. Selanjutnya, manajemen dipegang C.W. Weijs, bekas insinyur kepala yang membangun saluran irigasi di $\mathrm{P}$ en $\mathrm{T}$ Lands. Ia membangun jaringan irigasi dengan memanfaatkan aliran Sungai Cipunagara. Konsentrasi irigasi berada di wilayah $\mathrm{P}$ en $\mathrm{T}$ bagian timur, yakni Ciherang yang menjadi pusat administrasi pekebunan $\mathrm{P}$ en $\mathrm{T}$. Keberadaan irigasi mampu meningkatkan hasil panen secara drastis. Bila sebelum ada irigasi petani mampu panen sekali saja dalam setahun, setelah itu dapat panen dua kali (Padmo, 2004: 64-65).

Anglo-Dutch Plantation of Java Limited sejak 1911 menguasai pemilikan atas tanah Pamanukan dan Ciasem (Stibbe, 1921: 371). Sebagian besar tanah perkebunan warisan Hofland terletak di lereng Gunung Tangkubanperahu yang tersebar di beberapa kademangan. Sebagian besar berupa perkebunan kopi dan karet. AngloDutch Plantation of Java Limited membeli saham kepemilikan sebesar $f$ 706.485,00. Anglo-Dutch Plantation kemudian menjadi Holding Company $P$ en $T$ Maatschapij yang berkedudukan di London. Pada masa ini, dibuka kembali perusahaan perkebunan (onderneming) sebagai berikut:

Tabel 2. Nama Kebun dan Tanaman Komoditasnya

\begin{tabular}{|c|c|c|c|c|c|}
\hline \multirow[t]{2}{*}{ No. } & \multirow{2}{*}{ Daerah } & \multirow{2}{*}{$\begin{array}{c}\text { Nama } \\
\text { Perkebunan }\end{array}$} & \multicolumn{3}{|c|}{ Komoditas } \\
\hline & & & Teh & Kopi & Karet \\
\hline 1. & Subang & Sumurbarang & & & $\sqrt{ }$ \\
\hline \multirow[t]{2}{*}{2.} & \multirow[t]{2}{*}{ Kalijati } & Jalupang & & & $\sqrt{ }$ \\
\hline & & Cipeundeuy & & & $\sqrt{ }$ \\
\hline \multirow[t]{2}{*}{3.} & \multirow[t]{2}{*}{ Pagaden } & Cigarukgak & & $\sqrt{ }$ & $\sqrt{ }$ \\
\hline & & Manyingsal & & $\sqrt{ }$ & $\sqrt{ }$ \\
\hline 4. & Sagalaherang & $\begin{array}{l}\text { Legokmara } \\
\text { (Tambakan) }\end{array}$ & $\sqrt{ }$ & & \\
\hline
\end{tabular}
tanah partikelir mendorong pemerintah membeli tanah-tanah P en T pada 1920. Keadaan itu membuat pemilikan lahan oleh tuan tanah semakin berkurang, sementara kedudukan pemerintah semakin kuat. Bagi penduduk, kebijakan peme- 
rintah dirasakan cukup menguntungkan. Secara berangsur-angsur penduduk pribumi memiliki hak perorangan atas tanah dengan kewajiban tertentu di tanah yang dimiliki pemerintah, seperti membayar pajak tanah, kerja wajib, ronda, dan sebagainya. Sejak 1920, lurah-lurah digaji dengan uang kas yang berasal dari iuran penduduk. Kondisi tersebut berbeda sebelum 1920, para lurah mendapat penghasilan dari premi cuke, gaji bulanan dari perkebunan, dan penghasilan lainnya (ANRI, 1976: xxxviii).

Perubahan pemilikan tanah dari tanah partikelir menjadi tanah pemerintah berdampak signifikan terhadap penduduk pribumi. Para penduduk lebih leluasa mengembangkan usaha di sektor pertanian rakyat. Tentu saja, yang terpenting bagi penduduk adalah kepastian hak milik. Mereka dapat mengajukan pemilikan tanah yang dibeli dari pemerintah atau tanah yang telah dikuasai pemerintah (Padmo, 2004: 56). Pembelian tanah atas tanah partikelir oleh pemerintah tidak berjalan mulus. Pendanaan dan aparat penyelenggaranya menjadi permasalahan tersendiri (Effendhie, 1990: 90).

Hasil penjualan tanah digunakan para pengusaha untuk membeli tanah-tanah di luar Subang. Tanah-tanah itu dijadikan onderneming-onderneming. Luas tanah erfacht kira-kira 14.000 hektar, sedangkan tanah-tanah konsesi seluas 2.800 hektar.

Tabel 3. Nama Kebun P En T di Luar Subang dan Komoditasnya

\begin{tabular}{|c|c|c|c|c|c|c|}
\hline \multirow{2}{*}{$\begin{array}{c}\text { NO } \\
\text {. }\end{array}$} & \multirow{2}{*}{ DAERAH } & \multirow{2}{*}{ ONDERNEMING } & \multicolumn{4}{|c|}{ KOMODITAS } \\
\hline & & & & KOPI & KARET & KINA \\
\hline \multirow[t]{2}{*}{1.} & Sukabumi & Bojongasih & $\sqrt{ }$ & & $\sqrt{ }$ & \\
\hline & & Malinggu & $\sqrt{ }$ & & $\sqrt{ }$ & \\
\hline 2. & Cibeber & Gg. Campaka & $\sqrt{ }$ & & $\sqrt{ }$ & \\
\hline 3. & Semarang & Kalimas & $\sqrt{ }$ & & $\sqrt{ }$ & \\
\hline \multirow[t]{3}{*}{4.} & Garut & Neglasari & $\sqrt{ }$ & & & $\sqrt{ }$ \\
\hline & & Waspada & $\sqrt{ }$ & & & \\
\hline & & Ganjartemu & $\sqrt{ }$ & $\sqrt{ }$ & & \\
\hline \multirow[t]{3}{*}{5.} & Pekalongan & Pagilaran & $\sqrt{ }$ & & $\sqrt{ }$ & \\
\hline & Bandung & Cukul & $\sqrt{ }$ & & & $\sqrt{ }$ \\
\hline & & Pangalengan & $\sqrt{ }$ & & & $\sqrt{ }$ \\
\hline \multirow[t]{3}{*}{6.} & Sumedang & Cideruk & $\sqrt{ }$ & & & \\
\hline & & Margapala & $\sqrt{ }$ & & $\sqrt{ }$ & \\
\hline & & Margawindu & $\sqrt{ }$ & & $\sqrt{ }$ & \\
\hline 7. & Tasikmalaya & Palahlar & $\sqrt{ }$ & & $\sqrt{ }$ & \\
\hline 8. & Bojolali & Sukabumi & $\sqrt{ }$ & & & \\
\hline
\end{tabular}

Sumber: Disbudpar Subang (2002: 50)

Sebagai pengembangan dari ekstensifikasi $\mathrm{P}$ en $\mathrm{T}$, onderneming Sukamandi dibuka pada 1924. Onderneming Sukamandi yang merupakan perusahaan terbesar di Jawa dan Madura. Onderneming Sukamandi menghasilkan komoditas tapioka, sisal, dan kapuk (Disbudpar Subang, 2002: 50).
Selain onderneming Sukamandi, Wangunreja dan kebun karet lainnya menjadi sumber pendapatan penting bagi perusahaan. Pada 1933, produksi karet tertinggi mencapai $568.962 \mathrm{~kg}$. Waktu itu kebun Wangunreja administratur $\mathrm{T}$. Veldman (Wardini, 2010: 144). Perkebunan Pasirbungur memiliki pabrik pengolah- 
an latex. Di tahun 1929, di Hindia Belanda, pabrik pengolahan karet hanya ada dua, satu di Pasirbungur dan satu lagi di Sumatra Timur. Karet produk Pasirbungur dijual ke pabrik-pabrik ban di Amerika Serikat, karena kualitasnya baik (ANRI, 1976: XL).

E.J. Hammond mampu mengelola perusahaan dengan baik. Produksi komoditas perkebunan berkembang dengan pesat, baik di dataran rendah maupun dataran tinggi. Karena sakit, Hammond kembali ke Inggris hingga menghembuskan nafas terakhinya pada 1926. Penerusnya, G.C. Denham (1925-1933) dan H.J. Adams berhasil memajukan P en $T$ Lands. Pada pertengahan abad ke-20, $\mathrm{P}$ en $T$ termasuk perusahaan yang diperhitungkan. Perusahaan ini menjadi perusahaan perkebunan paling berkembang di wilayah Jawa (Anonim, 1938: 6).

Malaise (depresi besar) melanda dunia pada 29 Oktober 1929. ${ }^{3}$ Sendi perekonomian mengalami kelumpuhan. Daya beli masyarakaat menurun drastis. Angka pengangguran meningkat, karena Pemutusan Hubungan Kerja besar-besaran. Di Hindia Belanda kondisi serupa terjadi. Harga komoditas mengalami penurunan. Harga beras bahkan turun hingga 60 persen. Demikian pula, komoditas karet dan teh turut terkena imbas dari malaise. Harga karet jatuh hingga 0,11 gulden. Kondisi tersebut menyulitkan perusahaan. Di satu sisi harga komoditas yang terus turun, namun di sisi lain biaya produksi malah semakin meningkat. Biaya angkut, peralatan, dan pemasaran semakin mahal. Dalam kondisi demikian, pemerintah Hindia Belanda bersikeras tidak mau mendevaluasi guldennya. Pemerintah melakukan tindakan tidak populer dengan menurunkan gaji dan upah, serta menye-

\footnotetext{
${ }^{3}$ Depresi hebat atau yang biasa disebut malaise berawal dengan dibukanya pasar bebas dan berakhir dengan diobralnya 16 juta saham di bursa Wall Street, New York. Masyarakat berbondong-bondong menarik uang di bank dan terjadi likuidasi secara besar-besaran (Wardini, 2010: 39).
}

lenggarakan pajak-pajak baru. Dalam kondisi seperti ini, masyarakat petani di pedesaan yang paling merasakan penderitaan akibat kebijakan pemerintah (Wardini, 32010: 9).

\section{Perubahan Kebudayaan di Subang a) Pertumbuhan Penduduk}

Tingkat pertumbuhan penduduk, jauh sebelum masuknya industri perkebunan, dapat dikatakan bergerak secara perlahan. Umumnya kampung-kampung berpenduduk kurang dari sepuluh orang. Konsentrasi penduduk yang demikian, terutama terjadi di wilayah utara yang berawa-rawa dan sering dilanda banjir. Faktor lain yang juga berpengaruh adalah adanya tindakan kriminal dari para begal (perampok) yang mengganggu ketenteraman penduduk.

Setelah beroperasinya perusahaan perkebunan, jumlah penduduk meningkat drastis. Jumlah penduduk di wilayah Subang pada 1899 tercatat 175.342 jiwa. Pada 1917, jumlah penduduk meningkat menjadi 250.600 jiwa. Dari jumlah tersebut terdapat 100 orang Eropa dan 750 Timur Asing (Stibbe, 1921: 371).

Kota Subang menjadi semakin penting kedudukannya. Selain sebagai pusat administrasi $\mathrm{P}$ en $\mathrm{T}$, juga menjadi kedudukan kontrolir dan detasemen VeldPolitie. Dengan dibangunnya instalasi listrik, Kota Subang semakin berkembang, baik sebagai pusat pemerintahan maupun administrasi perkebunan (Disbudpar Kab. Subang, 2002: 48). Dengan demikian, kota Subang menjadi magnet bagi para pencari kerja maupun pedagang dari luar kota. Keberadaan jaringan transportasi berupa jalan pos dari Cisalak ke Sagalaherang dan jalan trem yang menghubungkan Subang dengan jalur jalan pos di utara mendorong dinamika sosial-ekonomi di wilayah ini. Tidak hanya Subang, kota kecil seperti Pagaden menjadi pusat kegiatan ekonomi yang terhubung dengan pasar di kota subdistrik atau pasar desa yang ada di sekitarnya (Padmo, 2004: 66). 
Tabel 4. Luas Wilayah dan Kepadatan Penduduk

\begin{tabular}{ccll}
\hline \multirow{2}{*}{ Kecamatan } & $\begin{array}{c}\text { Luas Wilayah } \\
\left(\mathbf{k m}^{\mathbf{2}}\right)\end{array}$ & \multicolumn{2}{c}{ Kepadatan Penduduk/km } \\
\cline { 3 - 4 } & 237,99 & $\mathbf{1 9 2 0}$ & $\mathbf{1 9 3 0}$ \\
\hline Subang & 286,20 & 133 & 239 \\
\hline Pegaden & 220,90 & 192 & 135 \\
\hline Kalijati & 151,80 & 267 & 306 \\
\hline Pamanukan & 145,71 & - & 273 \\
\hline Binong & 164,62 & - & 269 \\
\hline Pusakanegara & 184,90 & 246 & 222 \\
\hline Ciasem & 205,13 & - & 251 \\
\hline Pabuaran & 112,43 & - & 203 \\
\hline Purwadadi & 247,28 & 175 & $\mathbf{2 0 1}$ \\
\hline Sagalaherang & 189,80 & 171 & \\
\hline Cisalak & $\mathbf{2 0 5 1 , 7 6}$ & $\mathbf{1 3 3}$ & \\
\hline Total Kabupaten & & & \\
\hline
\end{tabular}

Sumber: Effendhie (1990: 46)

Kecenderungan kenaikan jumlah penduduk cukup signifikan dalam kurun waktu 1920-1930. Perbaikan kualitas hidup dan pengadaan sarana dan prasarana penunjang yang semakin memadai menyebabkan pertumbuhan penduduk terus meningkat. Kepadatan penduduk pada 1920 mencapai $133 / \mathrm{km}^{2}$. Sepuluh tahun kemudian (1930), kepadatan penduduk meningkat menjadi $201 / \mathrm{km}^{2}$. Pada tahuntahun itu, tingkat kesehatan penduduk dapat dikatakan cukup baik. Sementara itu, angka kelahiran mencapai 2.548 orang per tahun Angka kematian mencapai 11 dan 26 per 1000-nya. Meski demikian, Residen Povelier menyangsikan angka-angka tersebut. Ia beranggapan tidak semua kepala desa melaporkannya pada aparat pemerintah di onderdistrik (ANRI, 1976: xxxvii).

Kebanyakan penduduk yang berada di sebelah utara Subang adalah orangorang Jawa. Mereka adalah bekas prajurit Mataram yang tidak kembali dan para pendatang yang mencari kerja. Dari segi langgam bahasanya, penduduk di sepanjang wilayah utara mulai dari Distrik Pamanukan hingga desa-desa pantai onderdistrik Cipedes dan Cilamaya menggunakan dialek Cirebon. ${ }^{4}$ Kebanyakan orang-orang Sunda tinggal di Distrik Purwakarta, Distrik Sagalaherang, Distrik Pagaden, Distrik Cikampek, dan Distrik Karawang. Sementara itu, orang-orang Eropa bermukim di pusat kota, seperti di pusat Kota Subang dan pusat Kota Purwakarta. Selanjutnya orang-orang Cina bermukim di wilayah Karawang, Cilamaya, Purwakarta, dan Pamanukan. Hampir semua orang-orang Cina ini bekerja sebagai pedagang dan pengusaha toko kelontong (Imadudin, 2013: 45).

Dari sisi keagamaan, sebagian besar orang-orang pribumi hampir semuanya beragama Islam (ANRI, 1976: xxxvi). Orang-orang Eropa pada umumnya beragama Kristen, sedangkan orang-orang Cina menganut kepercayaan Kong $\mathrm{Hu}$ Chu, agama Buddha, dan Kristen.

Ditinjau dari aspek kebudayaan, terdapat perbedaan antara penduduk di Subang Utara dan Subang Selatan. Penduduk yang bermukim di wilayah Subang bagian selatan relatif lebih tertutup dibandingkan penduduk yang bermukim di

4 Banyak buruh musiman yang datang ke Pamanukan untuk ikut memanen. Di antara mereka adalah santri-santri yang berasal dari Pesantren Tegalgubug dekat Arjawinangun, Indramayu (ANRI, 1981: xxviii). 
bagian utara. Masyarakat Subang bagian selatan ini lebih menampakkan nilai-nilai kepatuhan dan kehalusan. Sementara itu, penduduk di Subang Utara lebih terbuka dengan karakternya yang lebih keras. Dikotomi geografis antara pesisir dan pedalaman, meski harus pertimbangkan kembali, nyatanya memberi dampak terhadap corak hubungan kerja di perkebunan (Imadudin, 2013: 47).

Kapitalisme perkebunan telah memberikan pengalaman bagi penduduk untuk hidup bersama dengan latar etnis yang berbeda-beda. Dalam interaksinya, masyarakat baru mengembangkan nilai-nilai kehidupan yang toleran dan mendukung nilai-nilai ekonomi.

\section{b) Mata Pencaharian}

Corak kehidupan masyarakat di kawasan Subang bersifat homogen dengan tingkat diferensiasi sosial yang rendah. penduduk di kawasan Subang merupakan masyarakat tradisional yang kehidupannya dicirikan dengan ekonomi subsistensi. Interaksi di antara masyarakatnya bersifat komunal dengan solidaritas yang dibangun secara emosional. Kebanyakan penduduk adalah petani. Dengan kuatnya sistem gotong-royong, usaha produksi tidak memerlukan uang sebagai upah. Pengerahan tenaga dilakukan menurut pertukaran (Muhsin, 2009: 300).

Sebelum masuknya intervensi kolonial, penggarapan lahan pertanian didasarkan pada bagi hasil. Meskipun demikian, ada beberapa pemilik tanah yang menggarap tanahnya menggunakan tenaga pembantu-pembantunya sendiri. Pola tanam sangat bergantung pada hujan. Akibatnya bila kemarau panjang, petani mengalami gagal panen (ANRI, 1976: xxxii).

Penduduk berkenalan dengan tanaman yang laku di pasaran Eropa setelah pemberlakukan wajib setor. Mereka diwajibkan membayar pajak (contingenten), setoran wajib (verplichte leveranties), melakukan kerja rodi dengan mencari kayu, bekerja di galangan kapal dan rumah para pembesar. Penduduk tidak memiliki hak atas tanah, dan hanya memiliki hak pinjam (hak gaduh). VOC yang memiliki tanah, dan meminjamkannya pada bupati. Bupati meminjamkannya pada rakyat, termasuk orangorang Cina (Disubdpar Subang, 2002: 32).

Dengan semakin meluasnya kewajiban penduduk, desa-desa baru dibuka. Tempatnya berada pada lahan yang letaknya agak tinggi. Dataran rendah digunakan untuk pertanian. Setiap keluarga mendapat tanah kering $1 / 4$ bau untuk pesawahan dan 2 bau untuk tegalan (ANRI, 1976: xxxiv).

Pola jual-beli dengan sistem barter masih menjadi pemandangan yang umum di pedalaman, meskipun penggunaan uang sebagai alat tukar berlangsung sampai dasawarsa pertama abad ke-19. Pembayaran pajak ditukar dengan hasil pertanian. Uang logam yang terbuat dari tembaga lebih banyak digunakan dibandingkan yang terbuat dari perak. Penduduk dan pedagang kurang menyenangi pemakaian uang kertas, karena nilainya terus merosot (Padmo, 2004: 72).

Kerajinan rakyat terkonsentrasi di beberapa tempat. Di Ciasem terdapat kerajinan menenun layar dari gebang dan merajut jala. Di antaranya yang terkenal ialah layar "Kasang Jinem" dari Ciasem. Menganyam bambu menjadi pekerjaan sambilan penduduk di Kalijati, Pabuaran, dan Sagalaherang. Pembakaran periuk, batu merah, dan genting hampir merata di seluruh daerah. Kerajinan pandai besi mulai berkembang sejak tahun 1960-an di Cisalak, Pamanukan, dan Sagalaherang. (ANRI, 1976: xliii).

Para pendatang membawa nilai-nilai baru. Buruh dari Jawa menyebarkan pengetahuan baru mengenai cara-cara bersawah. Sebagaimana dinyatakan Broersma (1912), masyarakat setempat ketika itu belum mengenal cara bercocok tanam di sawah (Padmo, 2004: 71). Kapitalisme perkebunan telah mengalihkan mata pencaharian penduduk dari bertani menjadi pekerja di perkebunan. Dari petani menjadi buruh tidak saja berarti peralihan 
profesi, tetapi perubahan pada aspek nilainilai budayanya.

\section{c) Gaya hidup}

Penduduk yang bekerja di perkebunan sering dilanda kejenuhan. Oleh karena itu, para tuan tanah menyelenggarakan hiburan bagi para buruhnya yang biasanya bertempat di lokasi kebun atau pemukiman para buruh. Waktunya, terutama di harihari libur dan selepas kerja untuk melepaskan penat. Kegiatan hiburan ini tidak saja untuk memenuhi kepentingan para penduduk yang bekerja, tetapi juga kepentingan tuan tanah sendiri dalam hal menyambut dan menghibur para tamunya. Bagi tuan tanah, mereka memiliki sarana hiburan tersendiri. Gedung societet yang dibangun pada masa Hofland menjadi tempat bersosialisasi sekaligus hiburan dengan adanya dansa-dansi, nyanyian, permainan biliard, dan sebagainya.

Perkembangan hiburan rakyat di wilayah perkebunan berpengaruh pada ketertarikan tuan tanah asing terhadap kesenian Sunda. Mereka akhirnya menjadi pengayom kesenian di lingkungan perkebunan (Herdiani, 2013). Para administratur perkebunan sejak zaman Hofland sering menghibur tamunya dengan musik gamelan (Broersma, 2008: 127). Dalam kisah perjalanan Jan ten Brink diceritakan bahwa para tamu yang datang ke tanah $\mathrm{P}$ en $\mathrm{T}$ Lands disambut dengan kemeriahan berupa alunan gamelan dan tarian-tarian (ten Brink, 1894: 7).

Para administratur berupaya membangun citra baik di kalangan masyarakat. Hiburan yang didatangkan dari luar lebih merupakan bentuk belas kasih terhadap buruh. Padahal hal tersebut dilatarbelakangi oleh pertimbangan ekonomis. Ongkos yang dikeluarkan untuk mendatangkan buruh-buruh baru tentu lebih mahal dibandingkan menggelar hiburan.

Pihak perkebunan $\mathrm{P}$ en $\mathrm{T}$ menggelar hiburan rakyat bagi orang-orang Sunda (een Soendaneesch volksvermaak) dengan mengundang ledek atau hiburan lainnya. Biasanya kesenian ini didatangkan sekali dalam seminggu atau waktu-waktu tertentu. Dalam jangka waktu yang cukup lama, pihak perkebunan mengontrak para pemain dan penari doger kontrak untuk menghibur para buruh. Sebutan doger kontrak sangat mungkin dikaitkan dengan istilah kuli kontrak dalam sistem perkebunan. Kemungkinan lain doger dikontrak oleh para tuan tanah sebagai pemilik dan pengelola perkebunan. Para perempuan penghibur tersebut didatangkan dari pantai utara Pamanukan dan Semarang yang ditampung di rumah khusus (Herdiani, 2013).

Ronggeng, yang sering disebut dalam bahasa Belanda sebagai Javaansche rongging (ronggeng Jawa), bertujuan menghibur sekaligus memberi kesenangan pada para buruh (ten Brink, 1894: 30). Istilah lain dari ronggeng adalah doger atau dombret. Doger berasal dari kata 'ngadog-dog-an anu beger (mengiringi yang tengah gandrung).

Bagi pemerintah, pesta ronggeng di perkebunan cukup merepotkan karena terjadi kriminalitas yang menyertainya. Di Batavia dan Bogor muncul pelarangan terhadap pertunjukan ronggeng. Para buruh menghabiskan seluruh uang hasil jerih payahnya bekerja untuk perempuan malam, minuman keras, berjudi, dan menghisap candu. Larangan pertunjukan ronggeng bahkan tanpa meminta persetujuan para tuan tanah. Pemerintah melarang dengan keras pesta ronggeng pada 1880 . Namun kemudian, pada 1881 larangan tersebut melonggar. Ada kekhawatiran bahwa para buruh pergi meninggalkan perkebunan. Pada masa selanjutnya, pesta ronggeng justru memeriahkan kehidupan perkebunan. Pemilik kebun berkepentingan untuk menjaga para buruh tetap berada di wilayah perkebunan (Prabaningtyas, 2013: 4).

Ronggeng atau dombret merupakan penari wanita yang memiliki kemampuan menyanyi dan menari. Kesenian ini dipertunjukkan di arena terbuka yang jauh dari rumah penduduk. Biasanya para nayaga (para penabuh gamelan) menggelar 
tikar sebagai alas tempat duduknya. Gelapnya malam diterangi oleh colen, yaitu sejenis obor yang berasal dari bahan bambu. Sebagai alat musik pengiringnya dipergunakan ketuk, kecrek, kendang, rebab, dan goong kecil. Musiknya yang riang mengundang hasrat buruh untuk datang dan ikut menari. Tatalu (musik pembuka) mengawali pertunjukan sebagai tanda dimulainya tarian. Para ronggeng dan buruh menari bersama. Ronggeng menari dengan menonjolkan goyangan pinggul. Setelah menari, ronggeng akan menerima uang sawer (Weintraub, 2010: 207).

Selama hiburan berlangsung, para penonton dapat meminta lagu kepada doger. Penari ronggeng dapat diajak ke luar arena pertunjukan oleh penari pasangannya ke tempat yang gelap untuk bercengkrama. Beberapa saat kemudian ronggeng kembali ke arena pertunjukan. Ia menyimpan uang pemberian penggemarnya ke dalam peti dekat panjak (pemain musik). Ronggeng menari kembali sambil menunggu pasangan berikutnya yang menari bersamanya. Pertunjukan sering berakhir hingga dini hari. Pertunjukan akan berakhir manakala para penanggapnya kelelahan atau kehabisan uang.

Kesenangan duniawi, seperti bermain judi dan minum-minuman keras menjadi bagian yang tidak terpisahkan dari hiburan para buruh. Ongkos yang harus dikeluarkan buruh untuk menikmati hiburan tersebut tidaklah kecil. Para buruh akan menghabiskan gaji mingguannya. Situasi yang disengaja ini tentu bukan sekadar menyalurkan hasrat hiburan para buruh. Bagi tuan kebun, hiburan tersebut merupakan strategi "menghibur sambil mengikat" untuk menjinakkan buruh.

Pihak perkebunan berusaha menghisap kembali pendapatan buruh melalui tangan ketiga. Pihak perkebunan sengaja membuka jalan bagi orang Cina untuk masuk dalam situasi sulit yang dialami buruh. Orang Cina memanfaatkan situasi dengan memberi pinjaman kepada para buruh yang kehabisan uang akibat berjudi. orang-orang Cina dengan senang hati memberi pinjaman dengan syarat harus dibayar minggu berikutnya. Dengan cara seperti itu, buruh akan merasa terikat sehingga tidak dapat meninggalkan perkebunan (Effendhie, 1990: 32).

Warisan keberadaan ronggeng di kawasan Subang pada masa P en T dapat ditelusuri dari perkembangan kesenian doger kontrak. Menurut cerita yang berkembang, tari doger berkembang sejalan adanya perkebunan besar. Sebelum dikontrak pengelola kebun, para ronggeng dan pengiringnya sengaja mengamen dari satu perkebunan ke perkebunan lain setelah buruh menerima upah. Kebiasaan menampilkan ronggeng di perkebunan diperkirakan masih bertahan hingga saat nasionalisasi mengingat kultur masyarakat pantai utara Jawa Barat masih identik dengan seni tersebut hingga sekarang.

Aspek hiburan menjadi salah satu indikator adanya perubahan kebudayaan pada masyarakat Subang pasca masuknya industri perkebunan. Tradisi mendatangkan ronggeng rupanya sudah menjadi gejala umum di lingkungan perkebunan untuk menciptakan menciptakan stabilitas.

\section{PENUTUP}

Kehadiran perkebunan besar di kawasan Subang telah mengubah realitas sosial dan budaya masyarakat. Masyarakat setempat yang hidup dalam suasana tradisi agraris tradisional harus beradaptasi dengan ekonomi perkebunan. Mereka mengganti sistem ekonomi barter dan pembayaran dalam bentuk natura dengan uang.

Perubahan kebudayaan tampak dalam meningkatnya jumlah penduduk. Dalam pandangan ekonomi klasik, sering dikatakan bahwa peningkatan populasi penduduk diartikan sebagai meningkatnya kesejahteraan. Memang, jumlah penduduk merupakan aset potensial yang dapat digunakan sebagai faktor. Oleh karena itu, semakin banyak penduduk, semakin banyak pula tenaga kerja yang dapat digunakan. Akan tetapi, pernyataan 
tersebut masih harus dikaji ulang, karena dalam konteks perkebunan, buruh yang berada di kasta terendah dalam stuktur masyarakat perkebunan tidak cukup menikmati kesejahteraan. Dengan kata lain, dibukanya perkebunan besar, kelompok orang Eropa dan Cina serta para elit pribumi yang justru hidup dalam kemakmuran. Selain penduduk yang sudah menetap sejak lama, para pendatang yang berasal dari berbagai daerah juga memberi corak yang khas dalam perubahan budaya masyarakat. Budaya masyarakat yang terikat dengan ekonomi subsistensi berubah menjadi ekonomi uang.

Perubahan juga tampak dalam berubahnya mata pencaharian penduduk. Buruh perkebunan adalah para petani yang bertransformasi menjadi buruh. Petani di Hindia Belanda bukan para pemilik tanah yang kaya, melainkan petani miskin. Perubahan dari petani menjadi buruh tidak disebabkan faktor akses pemilikan tanah. Akan tetapi, diferensiasi sosial yang terjadi secara masif.

Perubahan lain terjadi dalam gaya hidup masyarakat perkebunan. Seiring dengan beban kerja yang cukup tinggi dan upah yang diterima secara reguler menyebabkan mereka mencari hiburan. Dalam situasi demikian, pihak perkebunan memanfaatkannya dengan menyelenggarakan hiburan, seperti tayuban atau doger kontrak. Masyarakat yang menjadi buruh menghabiskan uangnya dalam hiburan seperti itu. Maka, terjadilah ketergantungan buruh terhadap pihak perkebunan.

Memang hampir dapat dipastikan bahwa proses perubahan merupakan hukum alam. Namun, tentu saja, perubahan akibat pembangunan dan modernisasi dapat direncanakan dengan baik, karena mereka yang terkena dampak tetap saja orang-orang yang tidak cukup memiliki akses untuk meningkatkan kehidupan ke arah yang lebih layak, seperti halnya buruh dan petani. Oleh karena itu, kegiatan pembangunan dan modernisasi hendaknya mempertimbangkan aspek-aspek sosial bu- daya secara lebih cermat agar meminimalkan kemiskinan struktural.

\section{DAFTAR SUMBER}

\section{Buku}

Anonim. 1938.

Short History of the Pamanoekan \& Tjiassemlands. Tp.

Indonesia. Arsip Nasional. 1976.

Memori Serah Jabatan 1921-1930

(Jawa Barat). Jakarta: ANRI.

Asdi, Armin et al. 2007. Sejarah Kabupaten Subang. Subang: Disbudpar Kab. Subang.

ten Brink, Jan. 1894.

Drie Reisschetsen. vierde druk. Leiden: A.W. Sijthoff.

Broersma, R. 1912.

De Pamanoekanen Tjiassem Landen. Batavia: Drukkerij Papyrus.

Disbudpar Subang. 2002.

Penyempurnaan Naskah Sejarah Kabupaten Subang. Subang: Disbudpar Subang.

Endraswara, Suwardi. 2006.

Metode, Teori, dan Teknik Penelitian Kebudayaan: Ideologi, Epistemologi, dan Aplikasi. Yogyakarta: Pustaka Widayatama.

Kartodirdjo, Sartono dan Djoko Suryo. 1991. Sejarah Perkebunan di Indonesia: Kajian Sosial-Ekonomi. Yogyakarta: Aditya Media.

Kartodirdjo, Sartono. 1992.

Pendekatan Ilmu Sosial dalam Metodologi Sejarah. Jakarta: Gramedia.

Ledeboer. tt.

Boschexploitatie op de Pamanoekan en Tjiasemlanden. Weltevreden: G. Kolff 7 co.

Mubyarto et al. 1992.

Tanah dan Tenaga Kerja Perkebunan: Kajian Sosial-Ekonomi. Yogyakarta: Aditya Media.

O'Malley, William. 1988.

"Perkebunan 1830-1940: Ikhtisar", dalam Anne Booth et al. Sejarah 
Ekonomi Indonesia. Jakarta: LPES. Weintraub, Andrew. 2010.

Hlm. 228.

Padmo, Sugijanto. 2004.

Bunga Rampai Sejarah Sosial-Ekonomi Indonesia. Yogyakarta: Aditya Media.

"Sejarah Kota dan Ekonomi Perkebunan". Makalah disampaikan pada Diskusi Sejarah, Balai Pelestarian Sejarah dan Nilai Tradisional Departemen Kebuda-yaan dan Pariwisata Jogjakarta, 11-12 April 2007.

Pahan, Iyung. 2008.

Panduan Lengkap Kelapa Sawit: Manajemen Agribisnis dari Hulu hingga Hilir. Jakarta: Penebar Swadaya.

Poesponegoro, Marwati Djoened dan Nugroho Notosusanto. 1993.

Sejarah Nasional Indonesia V. Jakarta: Balai Pustaka.

Pranoto, Suhartono W. 1995.

Jawa (Bandit-bandit Pedesaan): Studi Historis 1850-1942. Yogyakarta: Graha Ilmu.

Soekanto, Soerjono. 2006.

Sosiologi Suatu Pengantar. Jakarta: Raja Grafindo. Persada.

Stibbe, D. G. 1919.

Encyclopaedie van Nederlandsch-Indie. Tweede Druk. Deerde Deel (Soema-N). s'Gravenhage: Martinus Nijhoff.

Suparlan, Parsudi. 1995.

Orang Sakai di Riau: Masyarakat Terasing dalam Masyarakat Indonesia: Kajian mengenai Perubahan dan Kelestarian Kebudayaan Sakai dalam Proses Transformasi Mereka ke dalam Masyara-kat Indonesia melalui Proyek Pemulihan Pembinaan Kesejahteraan Masyarakat Terasing Departemen Sosial Republik Indonesia. Jakarta: Yayasan Obor Indonesia.

Syam. Nur. 2007.

Madzhab-Madzhab Antropologi.

Yogyakarta: LKis.

Wardini, Cici et al. 2010.

Dari Bumi Pasundan Menembus Dunia; Perjalanan Panjang PTPN VIII. Bandung: PTPN VIII.
Dangdut Stories: A Social and Musical History of Indonesia's Most Popular Music. New York: Oxford University Press.

\section{Tesis dan Monograf}

Effendhie, Machmud. 1990.

Dari Tanah Partikelir $P$ en $T$ Menuju Tanah Merdeka: Draft Pendahuluan Monografi (KAB) Subang 1900-1968". Bogor: Pusat Studi Pembangunan LPIPB.

Imadudin, Iim. 2013.

Kehidupan Sosial Ekonomi Buruh di Tanah Partikelir Pamanukan dan Ciasem (1910-1969). Tesis. Program Pascasarjana Fakultas Ilmu Budaya Universitas Padjadjaran. Bandung: UNPAD.

\section{Internet}

Herdiani, Een. "Doger" Rekonstruksi Warisan Seni Rakyat dari Hiburan ke Pertunjukan", diakses dari http://www.een herdiani.net/2013/10/dogerrekonstruksi-warisan-seni-rakyat.html, Tanggal 5 Feb-ruari 2014, Pukul 11.19 WIB.

Prabaningtyas, Nurul. "Pertunjukan Tayub dalam Analisis Dramaturgi (Studi Deskriptif Waranggana Tayub di Dusun Ngrajek, Desa Sambirejo, Kecamatan Tanjung-anom, Kabupaten Nganjuk)", diakses dari http://journal.unair.ac.id/ auto.search. php, Tanggal 16 Juni 2013, Pukul 23.00 WIB.

Purwanto, Bambang."Menelusuri Akar Ketimpangan dan Kesempatan Baru: Catatan Tentang Sejarah Perkebunan Indonesia" diakses dari http://sejarah. fib.ugm.ac. id/ artdetail.php?id=12, Tanggal 7 Oktober 2011 WIB.

Inglehart, Ronald and Wayne E Baker. "Modernization, Cultural Change, and the Persistence of Traditional Values". American Sociological Review, Feb 2000. Accessesed from http://my.fit.edu / gabrenya/cultural/readings/InglehartBaker-2000.pdf, date February 4th, 2014. 
